\title{
Decrease in Blasts
}

National Cancer Institute

\section{Source}

National Cancer Institute. Decrease in Blasts. NCI Thesaurus. Code C153228.

A semi-quantitative microscopic finding indicating that the amount of immature mononuclear cells in a sample from a certain subject has decreased when compared to a prior sample from the same subject. 